nuclear vacuole to permit the passage of the chromosomes from the spindle reservoir into the vacuole (at arrow in Fig. 3).

There are two assemblers attached to each nuclear vacuole, thus explaining the long-standing misconception, originating with Badian ${ }^{7,8}$, that the yeast cell contains two Feulgen-positive chromosomes. Fig. 4 is a phase-contrast (visible light) photograph showing both assemblers occupying their characteristic positions in the living cell. The turgid vacuole and the fainter but equally turgid spindle are characteristic of the rapidly growing yeast cell and suggest that hydrostatic pressure pushes the chromosomes into the vestibule and provides the current which moves the soluble nucleic acid through the membrane.

This work was supported by a research grant from the National Science Foundation $G-15619$.

Biological Research Laboratory, Carl C. Lindegren

Southern Illinois University, Carbondale, Illinois.

' Caspersson, T., Chromosoma, 1, 561 (1940).

${ }^{2}$ Caspersson, T., and Brandt, K., Protoplasma, 35, 507 (1941). McClary, D. O., Bowers, W. D., and Miller, G. R., J. Bact., 83, 276
(1962).

4 Porter, K. R., J. Exp. Med., 97, 727 (1953).

- Palade, G. E., J. Biophys. Biochem. Cytol., 1, 59 (1955).

- Lindegren, C. C., Nature, 189, 959 (1961).

7 Badian, J., Bull. Acad. Pol. Sci. Lett., B, Science Nat., 5, 61 (1937).

- Lindegren, C. C., The Yeast Cell, its Genetics and Cytology (Educa. tional Pub., Inc., St. Louis, 1949).

- Lindegren, C. C., Williams, M. A., and McClary, D. O., Antonie Van Leeuwenhoek, 22, 1 (1956).

\section{Occurrence of Sialic Acid in some Gram-positive and Gram-negative Pathogenic Bacteria}

Aaronson and Lessie ${ }^{1}$ searched for sialic acid in ten species of bacteria and detected it only among the Gram-negative organisms. In continuation of our findings with Pasteurella pestis ${ }^{2}$, we have screened many pathogenic bacteria for the presence of sialic acid.

The micro-organisms were grown in the conventional liquid media or nutrient agar as indicated. After testing for the purity of the cultures, they were washed out with saline in the case of agar growths and the bacterial mass collected by centrifugation. After washing once with water, the cells were triturated with cold acetone $\left(-20^{\circ} \mathrm{C}\right.$.) and acetone powders prepared as usual. Fractionation of these were made as reported earlier ${ }^{2}$ and the sialic acid estimated by the thiobarbituric method $^{3}$ after extraction of the chromogen with isoamyl alcohol to remove the colour produced by deoxyribose. We did not meet with the difficulties referred to by Forbes and Ruck ${ }^{4}$. The results obtained are given in Table 1. There is some destruction of sialic acid in the acid treatment and on hydrolysis.

In its sialic acid content also Past. pseudotuberculosis resembles closely Past. pestis. The Salmonella organisms, Bord. pertussis and Ps. pyocyaneus, contain sialic acid. The case of $V$. cholerae is of interest in that the sialic acid content is negligible or very low in the four strains studied. It is of interest to find out whether the presence of the receptor-destroying enzyme in this organism, which is a sialidase ${ }^{5}$, has anything to do with the low sialic acid content. Among the Gram-positive bacteria studied. sialic acid was not detected in $C$. diphtheriae, and there seems to be a trace in Staph. aureus. The definite presence of sialic acid in the Gram-positive Strep. faecalis does not confirm the belief ${ }^{1}$ that sialic acid is present only in Gram-negative organisms.

We thank Dr. M. K. Habbu, Mr. R. S. Karbhari, and Mr. A. S. Narasimhan for help in growing the cultures and checking the purities. We also thank the Haffkine Institute Diamond Jubilee Research Committee for the award of a senior fellowship to one of us (R. J. I.).

Haffkine Institute,
Bombay, 12 .

Roshan J. Iran

${ }^{1}$ Aaronson, S., and Lessie, T., Nature, 186, 719 (1960).

'Irani, R. J., and Ganapathi, K., Nature, 194, 1197 (1982).

'Warren, L., J. Biol. Chem., 234, 1971 (1959).

4 Forbes, M.; and Ruck, N. A., Proc. Soc., Exp. Biol. and Med., 108. 34 (1961).

${ }^{5}$ Burnet, P. M., McCrea, J. F., and Stone, J. D., Brit. J. Exp. Pathol. 27, 228 (1945). Gottschalk, A., Biochim. Biophys. Acta, 24, 649 (1957).

\section{Spermicidal Activity of Bacterial Endo- toxin}

THE endotoxins of Gram-negative bacteria are a group of macromolecular lipopolysaccharide complexes which, on administration to experimental animals, produce a wide variety of physiological and pathological alterations ${ }^{1,2}$. Despite the similarity of some of the pathological findings in these varied reactions neither a common factor nor a basic mechanism responsible for the pathogenesis of these reactions has been established, and there is evidence that

No.

Table 1. Sialio Acid Content of Various Bacteria

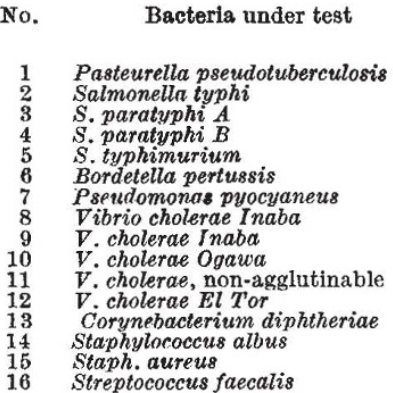

\begin{tabular}{|c|c|c|}
\hline \multicolumn{3}{|c|}{ Sialic acid content in $\mu \mathrm{gm} . / 100 \mathrm{~m}$} \\
\hline $\begin{array}{l}\text { Hot aqueous } \\
\text { extract }\end{array}$ & $\begin{array}{l}\text { Aqueous extraet } \\
\text { after hydrolysis }\end{array}$ & $\begin{array}{l}\text { Hydrc } \\
\text { of re }\end{array}$ \\
\hline 32 & 54 & \\
\hline 58 & 192 & \\
\hline 88 & 116 & \\
\hline 12 & 22 & \\
\hline 53 & 103 & \\
\hline 14 & 22 & \\
\hline 66 & 192 & \\
\hline 0 & 100 & \\
\hline 0 & 0 & \\
\hline 4 & 5 & \\
\hline 2 & 16 & \\
\hline 16 & 7 & \\
\hline 0 & 0 & \\
\hline 0 & 0 & \\
\hline 2 & 2 & \\
\hline 64 & 187 & \\
\hline
\end{tabular}

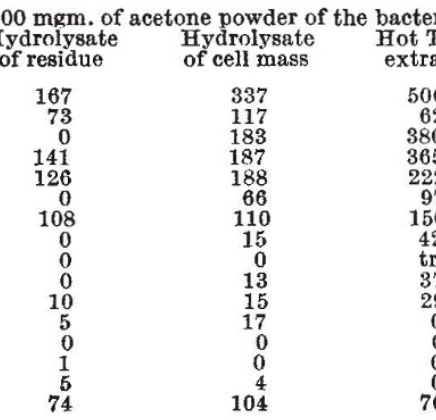

Past. pseudotuberculosis (No. 1) was grown in liquid medium at $37^{\circ} \mathrm{C}$. for 13 days. V. cholerae Inaba (No. 9) was grown in casein hydrolysate liquid medium at $37^{\circ} \mathrm{C}$. for $48 \mathrm{hr}$. C. diphtheriae (No. 13) was grown in liquid medium for 7 days at $37^{\circ} \mathrm{C}$. All the others were grown in nutrient agar and incubated at $37^{\circ} \mathrm{C}$. for $48 \mathrm{hr}$. The cold trichloroacetic acid extract of the acetone powder did not contain any sialic acid except in No. $3(48 \mu \mathrm{gm} . / 100 \mathrm{mgm}$.). 